\title{
GARCIA RUBIO, Alfonso. A caminho da maturidade na experiência de Deus. São Paulo: Paulinas, 2008. 227p.
}

\author{
Antonio Carlos Ribeiro*
}

A obra de Alfonso Garcia Rubio traz o melhor dos apontamentos das aulas de antropologia teológica dos cursos de graduação e pós-graduação em Teologia da Pontifícia Universidade Católica do Rio de Janeiro, lidando com conceitos como culpa, violência e sofrimento, a partir da psicanálise, e a luta contra o mal, o perdão do pecado e a afetividade aberta, a partir da teologia. Para tanto, ele descreve a peregrinação da sombra, pessoal e comunitária, à verdade; do infantilismo religioso à relação libertadora com o Abbá; e a superação da violência como experiência comunitária.

O autor tem consciência de que propor uma reflexão sobre a fé, a partir de saberes vistos popularmente como conflitivos e em busca da qualidade da fé nas comunidades, não atrai agentes de pastoral afeitos a respostas rápidas e nem formadores de padres, pastores, catequistas e religiosos atentos às exigências e objetivos das instituições eclesiais. Teólogo com visão transdisciplinar, dialoga com a psicanálise, a sociologia e a história, voltadas à compreensão das sociedades ocidentais.

O primeiro capítulo, Da "sombra" à verdade que liberta, começa com a desumanização iniciada na $1^{a}$ Guerra Mundial, numa Europa que é tida como centro do mundo - burguesia triunfante, economia capitalista e desenvolvimento nas artes e na educação - e que assiste estupefata ao massacre de cerca de 20 milhões de pessoas, no tratamento dispensado à Alemanha. Este é um

\footnotetext{
* Teólogo luterano, ex-secretário do Conselho de Igrejas Cristãs do Estado do Rio de Janeiro (Conic-Rio), Doutorando em Teologia (PUC-Rio). E-mail: antoniocarlosrib@gmail.com
}

Horizonte, Belo Horizonte, v. 7, n. 14, jun. 2009 
país derrotado e responsável pelo surgimento da $2^{\text {a }}$ Guerra, com 54 milhões de mortos, dividido e punido com prazos de reparação, num século encurtado pelo horror (massacres, ocupações, destruição de cidades, campos de concentração, genocídios e engenhos para matar muito e mais rápido), e chamado Breve por Hobsbawm, para quem o Brasil, sacudido por torturas, banditismo, desemprego e exclusão, é um monumento à negligência social.

A humanização é marcada por luzes (alimentação, saúde, escolarização, comunicação e transportes) e sombras (ambiguidades, repressão e projeção das negatividades, escondidas no inconsciente - a parte escura da personalidade - e criatividades, potencialidades e energias reprimidas). Lidar com as sombras supõe ver na verdade a melhor proteção contra o mal. Religiosos são tentados a negar sua sombra, que se torna patológica, com a repressão, e perigosa, com a projeção do que negamos em nós. Diante da solidão provocada, resta a coragem para nos defrontarmos com a sombra, que esbarra na arrogância. Solução: disciplina contra os sentimentos, que ajuda na aceitação, no desativar de emoções negativas e na libertação da culpa. Sombra coletiva é a da comunidade, manifesta no bode expiatório, especialmente as aureoladas de luminosidade e bondade. Jesus mostrou a sombra farisaica no judaísmo.

O perigo da sombra é se acomodar à mentira e dar a ela o nome de verdade. No hebraico, essa palavra significa firmeza, segurança e lealdade. Mentira fica perigosa ao ser transformada em alienação radical, passando do fingimento ao autoengano e projetando-se em Deus. A revisão obriga a lidar com a agressividade destrutiva, da qual se pode fugir para não se descobrir a mentira da própria vida (recalcar o homem sombrio e falar de vida santificada) ou, penetrados pelo ser, admitimos a carência do não ser e desenvolvemos a coragem de agir na busca de mais ser. O maior pecador é quem foge à consciência de seu pecado. O reflexo na igreja é quando nos colocamos a serviço da conversão lúcida e da significação transparente da igreja. Quando reconheço a sombra, enxergo a verdade.

Em A superação do infantilismo religioso, o segundo capítulo, Garcia Rubio começa a utilizar conceitos da psicanálise para demonstrar que somos controlados por forças e instintos inconscientes. O autor segue as observações do psicanalista e teólogo Carlos Dominguez Morano, segundo o qual Freud critica a religião chamando-a de neurose - a pessoa religiosa fica prisioneira do conflito edipiano, com sua carga afetiva ambivalente de amor e ódio, transferida para Deus - e de ilusão - a pessoa religiosa fica prisioneira da experiência infantil, sendo incapaz de assumir a vida com responsabilidade - e distinguindo a teologia como reflexão da fé no âmbito da revelação, da psicanálise como investigação científica que questiona o comportamento da pessoa de fé, cuja 
vivência pode estar viciada. Freud indica que o desejo de onipotência está centrado na figura materna, à qual o bebê está fusionado simbioticamente, o que paralisa o amadurecimento afetivo. $\mathrm{O}$ pai possibilita o rompimento do fascínio e do narcisismo, e a criança descobre que não é o centro do mundo e aceita os próprios limites. O pai fusionado pela criança como onipotente morrerá, para surgir o pai real e limitado. Para Fromm, o amor a si mesmo permite amar e superar narcisismo e egoísmo, fazendo o princípio da realidade se impor em sua evolução psíquica.

O problema é quando a criança não supera o egocentrismo (onipotência e fusão na totalidade materna) e, já adulta, segue instrumentalizando os outros para seu próprio proveito. A teologia indaga como, nessas condições, uma pessoa pode "viver autêntica experiência do Deus de Jesus Cristo, o Deus revelado como Ágape?" (p. 77). Na religião, a experiência mística está enraizada no psiquismo próprio da primeira fase da vida do bebê, mas o crente deve superar a infantilidade de um Deus providente e a seu serviço, para encontrar-se com pessoas. No encontro adulto com o Deus bíblico, o crente deve superar a idolatria, passando do fantasma da regressão infantil ao símbolo que tem dinamismo e é aberto ao futuro. Assim, articula o místico e o profético no compromisso ético diante da história e do mundo criado.

A fé cristã em Deus Pai e a crítica freudiana à religião, o terceiro capítulo, aprofunda a necessidade do desejo de fusão da criança com a totalidade (mãe) e o acesso à vida adulta (pai) como fundamentais para a experiência religiosa madura. As formas positiva e negativa de resolução do complexo de Édipo, em diferentes graus, são fundamentais para lidar com a limitação da onipotência e do desejo, e, consequentemente, para lidar com a realidade e as frustrações da vida humana. As cristologias recentes respondem à crítica de Freud ao explicar que os títulos cristológicos são confissões pós-pascais (Schillebeeckx) e integram as palavras e ações de Jesus no contexto do seu projeto (Reino de Deus), das quais surgirá um novo modelo de relação com Deus, baseada na confiança e na fidelidade de Jesus a Deus Pai - a fonte do caráter da sua práxis - e caracterizada pela solicitude, que é contrária ao mal, não lhe reconhecendo a supremacia e nem lhe concedendo a última palavra, mas querendo o bem (Sobrino). Isso é simbolizado pelo fato de Jesus abandonar o deserto do Jordão e voltar à frutífera região da Galileia para se aproximar dos perdidos e excluídos, abrindo a salvação a outros seres humanos (Pannenberg).

No amor gratuito e na misericórdia sem limites ao filho reencontrado, o pai impulsiona para a plenitude e convida para a semeadura. As categorias que definem a experiência humana a partir da filiação são esperança, liberdade e ausência de temor (Queiruga), que propiciam desenvolver a autonomia, rejeitando o fantasma do homem-menino, o fruto narcisista do desejo infantil, a culpa e a 
neurose, para ser ele mesmo, acabando com a rivalidade Deus-Pai-Onipotente e criatura humana. Assim, acreditar na vida em plenitude não elimina as incertezas, as angústias e os questionamentos do viver humano, mas firma a confiança no Deus de misericórdia e amor gratuito, que fundamenta a liberdade, a solidariedade, a justiça e as relações ecológicas. Em Jesus não encontramos atitude infantil, narcisista, autoritária, alheia à própria responsabilidade, mas uma atitude que possibilita o crescimento do outro, autônomo e com identidade pessoal, libertando-o das ilusões narcisistas, encaminhando a saída de si para o encontro do outro, reconhecido e valorizado. Isso é, para a teologia, aceitar a criaturidade.

O desafio do mal-violência e a experiência cristã comunitária, que intitula o quarto capítulo, ajuda a reconhecer e a lidar com a violência aninhada no coração humano, aquela dos crimes mais cruéis, da guerra, do terrorismo, da violência praticada contra vítimas indefesas e contra países em desenvolvimento ou subdesenvolvidos, sangrando recursos da educação, saúde e da segurança dos mais pobres. Apontam-se aí três itinerários para lidar com a serpente venenosa que também nos habita.

O primeiro, de Edgar Morin, ensina a assumir o dasein (estar aí sem saber por quê), amar como antídoto à angústia, abraçar o outro na relação matripatriótica e reconhecer no outro o irmão humano. Só nos tornamos humanos pela fraternidade.

O segundo, de René Girard, constata como é legítimo canalizar a violência para a vítima expiatória de fora do grupo, que não exige vingança. O preço da humanidade é uma inumanidade, criadora da comunidade. A importância do sagrado é mostrar que a violência sacralizada, exterior ao homem e transcendente, é benéfica e resulta na paz. A violência surge do desejo mimético (o sujeito que deseja o objeto, mas precisa enfrentar o rival. A convergência de dois desejos sobre o objeto gera o conflito). Na morte de Jesus, acaba o ocultamento da violência, porque ele é morto, mas não fica como vítima culpável. No cristianismo, a inocência faz com que o sagrado fique desvinculado da violência, ao mesmo tempo que Jesus a transcende por ser modelo não rival, o Deus Ágape, feito homem não violento.

O terceiro, de Adolphe Gesché, mostra o diálogo com Deus, no qual Ele é o antimal e a única resposta, tornando essa a nossa luta conjunta. Uma das consequências é que Deus é deixado de lado e, ao enfrentar sozinho o mal, assume suas acusações - a culpabilidade do ocidente atual - razão pela qual volta a necessidade de que Deus viva para que o homem não morra. E, se a história é afetada pelo mal, a afirmação é sua resposta. Diante do mal na violência, é necessária uma atitude de combate e de posicionamento a favor da vítima, ao invés da culpabilização excessiva. Se o mal é 
insolvente, é necessário um ab-soluto para ab-solver, alguém totalmente alheio ao mal e à violência, a salvação de Deus mediante Jesus Cristo. A ética sozinha não basta. É preciso justiça e amor, com sua lógica de excesso e de gratuidade, para responder recriadoramente aos desafios do mal.

A superação da violência se dá pela afetividade amadurecida, vivida na subjetividade aberta. Os cristãos são chamados à auto-organização (Maturana, Varela), que faz o organismo e o metabolismo atuarem em rede, autorregulando homeostaticamente a capacidade de reprodução e regeneração. Como patrimônio dos seres vivos, a subjetividade encontra maior eco na afetividade humana. Objetivamos para ressubjetivarmos um anel recursivo incessante (Morin). Afetado, o sujeito experimenta emoções e expressa sua interioridade, através da afetividade ambígua (amor e hostilidade). A violência é testada na experiência comunitária sadia, sem estar imune aos arrogantes, com sua sensação interna de inferioridade, enquanto pessoas têm dificuldade para reconhecer suas qualidades e potencialidades, convivência na qual se podem criar sentimentos de aprovação e estima que possibilitam desabrochar potencialidades. Sem esse ambiente, as pessoas podem se retrair para se defender e se tornar subservientes e hipócritas, deformando a personalidade. A comunidade cria espaços de aprovação e desaprovação, nos quais se espera que a pessoa adulta continue a sua vocação, participando do serviço e ajuda mútuos, e sabendo oferecer e receber ajuda, numa atitude de perdão/reconciliação.

No último capítulo, A prioridade do perdão sobre a culpa, o autor cita o clássico $O$ pecado $e$ $o$ medo, de Jean Delumeau, obra que mostra como a noção de pecado se desenvolveu pelo medo provocado nos grandes infortúnios na Europa (a peste negra, 1348-1351, e as guerras de religião, 1648), gerando a atitude de desprezo pelo mundo, iniciada nos mosteiros e integrada à espiritualidade dos cristãos, católicos e reformados. O modelo monástico foi imposto, a vida conjugal ficou sujeita a suspeitas, a virgindade e a castidade passaram a ser exaltadas e a resignação diante das catástrofes e das injustiças, vistas como normais neste 'vale de lágrimas'. O pessimismo cresceu, até que nos séculos XVI e XVII desenvolveu-se a mais poderosa culpabilização coletiva da história, com o objetivo de salvar.

Os desdobramentos pastorais dessa orientação foram assimilados no ocidente: a mulher tida como perversa, o casamento visto como perigoso, tornando honesto o sexo infame; o medo do corpo (impureza, horror à nudez) transformou-se em pavor (hostilidade às danças, proibição dos banhos e condenação das canções de amor), acompanhado da crescente culpabilização. A pregação integrou temas como desprezo do mundo, glorificação da morte, julgamento, cólera de Deus e suplícios 
eternos. Resultado: "a agressividade, em vez de ser canalizada construtivamente, acabou sendo reprimida, voltando-se contra a própria pessoa e contra os outros (os pecadores)" (p. 196).

Isso levou o autor de volta à psicanálise, que não se pronuncia sobre conteúdos religiosos, mas busca entender o inconsciente do sujeito que com eles se relaciona. Desde o bebê, que mistura pulsões agressivas e libidinosas, referidas ao seio materno (bom, que o gratifica, e mau, quando ausente), parte da mesma mãe. O amor-ódio dá lugar à culpa persecutória, que autodestrói, e à depressiva, que repara. O herdeiro do pai no inconsciente é o superego, a lei e a proibição. A culpa faz parte da estrutura psíquica do ser humano e não é um invento religioso. Esse sentimento nos faz perceber o dano em nós e nos outros, ou pela omissão, orientando-nos aos valores. Ele toca em nosso narcisismo, atinge nossa autoestima e exige bodes expiatórios para dar vazão à culpa, pedir a difícil compreensão e ter no arrependimento, no nível psíquico, o sentimento de culpa sadio. O Deus Abbá de Jesus liberta da culpa e do mal feito a nós e aos outros. Para a salvação, o fundamental é a graça e o amor de Deus. A dificuldade, radicada no psiquismo, é "algo que nos impele ao sacrifício, a matar algo de nós como reparação prévia ao reencontro, porque não concebemos como o outro possa não necessitar de nada nosso para poder aproximar-se e perdoar" (p. 204). A teologia contrapõe-se a essa atitude, lembrando que na intrinsecamente boa criação de Deus não existe nada ontologicamente mau.

A obra de Garcia Rubio é um libelo contra o sofrimento humano impotente, castrante e caótico. Vale-se de teóricos da teologia, sociologia e psicanálise para revelar o sofrimento e buscar soluções para uma vida religiosa mais saudável. Andar na verdade é a melhor proteção contra as sombras e o mal. A atitude de Jesus não é infantil, narcisista, nem autoritária, mas possibilita o crescimento do outro, com autonomia e identidade, saindo de si para o outro e valorizando a afetividade madura e a subjetividade aberta. A todos que percebem as dores e sofrimentos dessa situação, que buscam alternativas pastorais e envolvem-se no esforço de humanizar a ação eclesial, recomendo a leitura. Calma e persistentemente. 